\title{
Onbirinci Sınıf Öğrencilerinin Düşünme Stilleri, Öğrenme Stratejileri ve Düşünme Stilleri ile Öğrenme Stratejileri Arasındaki İlişki*
}

\section{Thinking Styles of Grade $11^{\text {th }}$ Students, Learning Strategies and the Relationship between Learning Strategies and Thinking Style}

\begin{abstract}
Diren ÇELİK**, Orhan KUMRAL***
Öz: Bireyler yeni bilgiyi edinmek ve bir öğrenme görevini gerçekleştirmek için düşünme stillerini ve öğrenme stratejilerini kullanırlar. Bu araştırmanın amacı araştırmaya katılan öğrencilerin kullandıkları düşünme stilleri ile öğrenme stratejilerini belirlemek ve onların düşünme stilleri ile öğrenme stratejileri arasındaki ilişkiyi ortaya çıkarmaktır. Çalışma genel tarama modellerinden ilişkisel tarama modeline göre desenlenmiştir. Araştırmanın çalışma alanını rastlantısal olarak seçilen 5 farklı lise türünün Onbirinci sınıflarında öğrenim gören 389 öğrenci oluşturmuştur. Araştırmada düşünme stilleri ile ilgili elde edilen veriler "Düşünme Stilleri Ölçeği”; öğrenme stratejileri ile ilgili elde edilen veriler ise "Öğrenme Stratejileri Belirleme Ölçeğì" kullanılarak toplanmıştır. Verilerin çözümlenmesinde; frekans, yüzde, ortalama, standart sapma, t-testi, tek yönlü varyans analizi, Tukey HSD testi, Kruskal Wallis testi ve Pearson Momentler Çarpımı analizi yapılmıştır. Araştırma bulgularına göre; Onbirinci sınıf öğrencilerinin yasama, hiyerarşik, yargı ve liberal düşünme stillerini sıklıkla tercih ettikleri; Tutucu, oligarşik, lokal ve global düşünme stillerini ise en az tercih ettikleri saptanmıştır. Öğrenme stratejilerinde ise öğrencilerin anlamlandırma stratejilerini ve anlamayı izleme stratejilerini yoğun olarak kullandıkları; duyuşsal stratejileri, yineleme stratejilerini ve örgütleme stratejilerini ise daha az kullandıkları belirlenmiştir. Onbirinci sınıf öğrencilerinin sahip olduğu düşünme stili ile kullandıkları öğrenme stratejileri arasındaki ilişkiye bakıldığında, öğrencilerin kullandıkları düşünme stilleri ile öğrenme stratejileri arasında anlamlı ancak negatif yönde bir korelasyon olduğu tespit edilmiştir.
\end{abstract}

Anahtar Kelimeler: Düşünme stili, öğrenme stratejisi, lise öğrencileri

\begin{abstract}
Absract: Individuals to acquire new knowledge, thinking styles and learning strategies they use to perform a learning task. The aim of this research is to determine of learning strategies and thinking styles and uncover the relationship between learning strategies and thinking styles of the students participating it in. The study was designed according to the relational model of the survey method. Research sample is selected at randomly from these 5 different types of high schools has 389 students from grade $11^{\text {th }}$ classes. "Thinking Styles Inventory", and "Learning Strategies Determining Scale", data gathering instrument in this study. To analyze the data; number, percentage, mean, standard deviation, t-test, one-way ANOVA, Tukey HSD test, Kruskal-Wallis test and Pearson Product Moment analysis was performed. According to research findings; students of grade 11th as Type 1 conceptualized thinking styles prefered as legislative, hierarchical, justice and liberal thinking styles frequently. The strategy used by students in learning strategies and understanding the meaning of the intensive monitoring strategies, affective strategies, recurrence strategies and organizational strategies are determined to use less. Students of grade 11th think with their own style to reveal the relationship between learning strategies, while looking at the total correlations of all types of schools, thinking styles used by students are found to have a negative correlation between learning strategies.
\end{abstract}

Keywords: Thinking style, learning strategy, high school students

\footnotetext{
* Bu çalışma, ikinci yazarın danışmanlığında yapılan yüksek lisans tezinin bir özetidir.

** Bilim Uzmanı, e-mail: direncelikk@ hotmail.com

**** Yrd.Doç.Dr., Pamukkale Üniversitesi Eğitim Fakültesi, Denizli-TÜRKIYYE, e-mil:okumral@ pau.edu.tr
} 


\section{Giriş}

Bireyler gerek günlük yaşamlarını sürdürürken gerekse öğrenme sürecinde istendik davranışlar edinmeye çalışırken, bazı eğilimler göstermekte veya çeşitli yollar tercih etmektedirler. Zihnin kullanımındaki tercihe dayalı bu farklılıklar, farklı stilleri oluşturmaktadır. Sternberg ve Zhang (2005), Sünbül (2004) ile Buluş’a (2005) göre stil, bir yetenek olmasa da sahip olunan yeteneklerin kullanımındaki tercih olarak tanımlanmaktadır. Ayrıca stil, yeteneklerden daha çok eğilimleri ifade eden bir kavramdır. Sternberg'e (1997) göre stil değişebilir, öğrenilebilir, ögretilebilir bir yapıdır. Riding ve Rayner'e (1998) göre ise stilin fiziksel bir temeli vardır ve bütünüyle bireye özgü, sabit ve değişmezdir. Alanyazında öğrenme stili, bilişsel stil ve düşünme stili adı verilen belli başlı üç değişik stil kavramı göze çarpmaktadır. Bu farklı isimler kimi zaman aynı kavramı ifade etmede kullanılmıs, kimi zaman da aynı isim farklı kavramlara verilmiştir (Eyüpoğlu, 2010).

Stiller, insan üzerinde etkili olan bireysel farklılık değişkenlerinden biri olarak uzun yıllardan beri incelenmektedir. 1950'lerden 1970'lerin sonlarına kadar stillerle ilgili pek çok kuram ve model oluşturulmuştur (Zhang, 2000). Emir'e göre $(2011,78)$ "Bu kuramların ilki Kolb'un yakınsak, ıraksak, benzetim ve yerleştirme şeklinde ayrıştırdığı öğrenme stillerinin dördünü temele alan kuramıdır. İkincisi Riding'in Bilişsel Stillerin Boyutu kuramıdır. Üçüncüsü Biggs ve Entwistle tarafından öne sürülen Öğrenme Stilleri kuramıdır. Dördüncüsü ise bu çalışmanın da temellerinden birini oluşturan Sternberg'in Düşünme Stilleri kuramıdır". Alanyazın incelendiğinde, doğrudan sınıf içi durumlara, öğrenme-öğretme ve değerlendirme süreçlerine ilişkin en kapsamlı kavramsallaştırmanın Sternberg'in (1997) Zihinsel BenlikYönetimi Kuramı ile yapıldığı görülmektedir. Sternberg'in kuramı bir düşünme stilleri kuramıdır. Kuram temelindeki araştırmalar özellikle Amerika Birleşik Devletleri'nde Robert Sternberg ve arkadaşları ile Hong Kong'da Li Fang Zhang tarafindan yapılmıştır. Ancak Türkiye'de Buluş (2001, 2006), Balkis ve Isiker (2005) ve Duru (2004) tarafindan yapılan çalışmaların dışında henüz yeterli bir anlayış oluşturacak düzeyde çalışmaya rastlanamamaktadır.

1990'lı yılların başlarında geliştirilen Zihinsel Benlik-Yönetimi Kuramı'ndaki temel görüş, dünyaca yaygın olan yönetim dallarına ve yönetim türlerine benzer şekilde insanların da farklı düşünme stillerine sahip olmasıdır (Buluş, 2005). Sternberg (1997) hükümet metaforuyla dünyayı anlamlandırmak için düşünmelerimizi organize etmekte kullandığımız stilleri bağdaştırmaktadır. Nasıl ki bir toplum kendini yönetme ihtiyacı duyuyorsa bizim de kendimizi yönetmeye ihtiyacımız vardır. Sternberg (1997) kuramı şu şekilde açıklamıştır: "Herkesin zihninde bir hükümet vardır ve tıpkı hükümet gibi kendini farklı yollarla yönetir, önceliklerini belirlemeye, dünyadaki değişimlere kendi inanç ve değerleri doğrultusunda tepki vermeye ihtiyacı vardır. Bu çerçevede düşüncelerini ve eylemlerini iç ve dış gereksinimlere uygun bir biçimde organize etmektedir. Dünyadaki hükümet formlarına bakıldığında birbirinin aynı olmadığ 1 görülmektedir" (s. 20). Bu sebeple kurama göre formlar, düşünmeyi organize eden bireyin zihninin dış dünyaya yansımasına olanak tanımakta ve düşünmelerimizi organize etmedeki farklı yolları temsil etmektedir (Sternberg, 1997). Sternberg'in yaklaşımında hükümetin işleyişine benzer bir yap1 olarak; işlevler (yasama, yürütme, yarg1), biçimler (monarşik, hiyerarşik, oligarşik, anarşik), düzeyler (global, lokal), konular-alanlar (içsel, dişsal) ve eğilimler (liberal, Tutucu) olmak üzere beş kategori (temel boyut, faktör) altında 13 düşünme stili görülmektedir. Kurama dayalı olarak 13 düşünme stilinin karakteristik özellikleri ayrıntılı olarak örneklerle Tablo 1'de sunulmuştur.

Sternberg'e (1994) göre tercihlerimiz yere ve duruma göre değişiklik gösterse de her kategoriden bir düşünme stilini tercih etme eğilimindeyiz. Örneğin, iş yaşamında yasama (yeniliklere açık olma, yaratıcı) düşünme stilini tercih eden bir öğretmen, evde aile düzenini devam ettirebilmesi ve sorumluluklarından dolayı yürütme stilini tercih edebilir. Kuramda bireylerin günlük bilişsel etkinliklerini nasıl düzenleyip yönettikleri sorusunun yanıtı aranmaktadır. Kurama göre insanlar, günlük faaliyetlerini düzenlemede kendileri için en uygun 
ve kendilerini en rahat hissedebilecekleri düşünme stillerini tercih etme eğilimindedirler (Duru, 2004).

Tablo 1. Zihinsel Benlik Yönetimi Kuramına Göre Düşünme Stilleri

\begin{tabular}{|c|c|c|}
\hline $\begin{array}{l}\text { DÜŞÜNME } \\
\text { STİLLERİ }\end{array}$ & DÜŞÜNME STILLLERINIIN GENEL ÖZELLIKKLERİ & ÖRNEKLER \\
\hline \multicolumn{3}{|l|}{ İŞLEVLER } \\
\hline Yasama & $\begin{array}{l}\text { Yaratıcı, icat edici, yenilikçi, fikir üreten, işlerinde } \\
\text { kendi yollarını kullanmaktan hoşlanan. }\end{array}$ & $\begin{array}{l}\text { Fen projeleri yapmayı, şiir veya hikâye yazmayı, orijinal } \\
\text { sanatsal işler yaratmayı severler }\end{array}$ \\
\hline Yarg1 & Yargılamayı, değerlendirmeyi seven. & $\begin{array}{l}\text { Diğerlerinin işlerini eleştirmeyi, eleştirel yazılar yazmayı, } \\
\text { dönüt ve tavsiye vermeyi severler. }\end{array}$ \\
\hline \multicolumn{3}{|c|}{ FORMLAR / BİÇIMLER } \\
\hline Monarşik & Tüm enerjileriyle aynı anda tek işe ve amaca odaklanan. & $\begin{array}{l}\text { Fen bilimleri, tarih, sanat hangi alanda olursa olsun tek bir } \\
\text { projeyle ilgilenmeyi severler. }\end{array}$ \\
\hline Oligarşik & $\begin{array}{l}\text { Bir kerede birçok işi yapan ve öncelik belirlemede } \\
\text { sorun yaşayan. }\end{array}$ & $\begin{array}{l}\text { Okuma anlamaya, sorunlarına yeterli zamanı ayırmayı severler } \\
\text { fakat standart sözel - yetenek testini bitiremeyebilirler. }\end{array}$ \\
\hline Anarşik & $\begin{array}{l}\text { Problemlere rastgele bir yaklaşım sergileyen, } \\
\text { sistemlerden ve rehberlikten kaçınan }\end{array}$ & $\begin{array}{l}\text { Konuşmalarında bir noktadan diğerine atlar, işlere başlar fakat } \\
\text { bitiremezler. }\end{array}$ \\
\hline \multicolumn{3}{|l|}{ DÜZEYLER } \\
\hline Bütünsel & $\begin{array}{l}\text { Resmin bütünüyle, genel çerçeve ve soyut düşünceyle } \\
\text { uğraşan. }\end{array}$ & $\begin{array}{l}\text { Bütünsel mesaj veren yazılar yazmayı, sanat eserleri } \\
\text { oluşturmayı severler. }\end{array}$ \\
\hline Ayrıntıc1 & Detaylar, özel ve somut düşüncelerle uğraşan. & $\begin{array}{l}\text { Sanatın detaylarını tarif edici ve birbirleriyle ilişkilerini tarif } \\
\text { eden yazılar yazmayı severler. }\end{array}$ \\
\hline \multicolumn{3}{|l|}{ YÖNELIM } \\
\hline \multicolumn{3}{|l|}{ EĞİLIMLER } \\
\hline Yenilikçi & $\begin{array}{l}\text { Yeni yöntemleri denemeyi seven, geleneklere karşı } \\
\text { koyan }\end{array}$ & $\begin{array}{l}\text { Önerilen yol olmasa da yeni bir aletin nasıl çalıştırılacağıyla } \\
\text { uğraşmayı severler. }\end{array}$ \\
\hline Tutucu & Denenmiş ve doğru yolları kullanmayı seven, gelenekçi. & $\begin{array}{l}\text { Geleneksel, denemiş yolla bir aleti çalıştırmayı, geleneksel sınıf } \\
\text { ortamlarında çalışmayı tercih ederler. }\end{array}$ \\
\hline
\end{tabular}

Kaynak: Dinçer ve Saracoğlu, 2011.

Düşünme stilleriyle ilgili bir diğer nokta da boyutlarıyla ilgili farklı kavramsallaştırmalar olmasıdır. Örneğin, düşünme stillerinin sınıflamasına ilişkin olarak gerçekleştirdiği bir çok çalışmada Zhang (2003, 2007), Zihinsel Benlik-Yönetimi Kuramı'nın üç tip stile indirgenerek incelenebileceğini belirtmiştir. Buna göre " 1 . Tip düşünme stilleri yaratıcı temelli ve kompleks yüksek bilişsel düzeyleri içeren yaratıcı özelliği baskın olan yasama, diğer insanları veya ürünleri değerlendiren yargı, bir anda bir çok işi yapabilen hiyeraşik, resmin bütünüyle ilgilenen global ve görevlere yeni yaklaşımlar getiren liberal stil; 2 . Tip düşünme stilleri norm temelli ve bilişsel karmaşıklığın daha düşük düzeylerde görüldüğü verilen görevleri uygulayan yürütme, detaylarla ilgilenen lokal, bir anda bir işle uğraşan monarşik, ve olaylara geleneksel yaklaşım sergileyen tutucu stiller; 3. Tip stiller ise rastgele çalışmayı yeğleyen anarşik, görevleri öncelik sırasında koymakta zorlanan oligarșik, kendi bașına çalışmayı seven içsel ve grupla çalışmaktan hoşlanan dişsal stillerdir" (Dinçer, 2009, 46). Bu araştırmada bulgular Dinçer (2009) ve Zhang'in (2003) da belirttiği üç tip stile göre düzenlenmiştir. 
Yapılan araştırmalara bakıldığında (Balgamış ve Baloğlu 2005; Çubukçu, 2004a; Buluş, 2005; Saracaloğlu, Yenice ve Karasakaloğlu, 2008; Dinçer, 2009) düşünme stili ile cinsiyet, yaş, sosyoekonomik düzey ve akademik başarı arasında ilişkiler bulunmuştur. Ayrıca bulgulara bakıldığında düşünme stillerinin öğrenme sürecinde, akademik başarı açısından önemli bir etken olduğu görülmektedir. Bu durum akademik başarıyı arttıran ve bu araştırmanın da diğer bir unsuru olan öğrenme stratejilerini ön plana çıkarmaktadır.

Çok değişik öğrenme stratejileri sınıflamaları olmasına karşılık, bu konudaki çalışmalara temel oluşturan sınıflamanın Weinstein ve Mayer tarafından yapılan sınıflama olduğu söylenebilir. Bu sınıflama kimi araştırmacılar tarafından tekrar düzenlenmiştir (Güven, 2004). Buna göre öğrenme stratejileri yineleme, anlamlandırma, örgütleme, anlamayı izleme ve duyuşsal stratejiler olarak beşli biçimde sınıflandırılmıştır (Tablo 2). Eldeki araştırmada da bu sınıflama esas alınmıştır.

Tablo 2. Özer, Demirel ve Weinstein'e Göre Ögrrenme Stratejileri Sintflamast

\begin{tabular}{ll}
\hline Stratejiler & Açıklamalar \\
\hline Yineleme stratejileri & Bilgilerin tekrarlanması, okuma ve kodlama \\
Anlamlandırma stratejileri & İlişkilendirme, dönüştürme ve özetleme \\
Örgütleme stratejileri & Düzenleme, bağ kurma ve sıralama \\
Anlamayı izleme stratejileri & Denetleme, düzenleme ve yürütme \\
Duyuşsal stratejiler & $\begin{array}{l}\text { Dikkati odaklama, yoğunlaşmayı sürdürme ve kendini } \\
\text { güdüleme }\end{array}$ \\
\hline
\end{tabular}

Not: Güven (2004) yararlanılarak oluşturulmuştur.

Öğrenme stratejileri üzerine yapılmış çalışmaların sonuçları incelendiğinde (Doğan 2002; Talu, 1997; Yıldız, 2003; Belet, 2005), eğitim sisteminde karşılaşlan temel problemlerin çözümü için öncelikle bireylere öğrenme stratejilerini doğru kullanabilme yeterliliğinin kazandırılması gerekliliği ortaya çıkmaktadır. Aynı zamanda toplumların geleceği, düşünebilen, yaratıcı ve muhakeme gücü yüksek bireyler yetiştirilebilmesiyle mümkündür. Bu bağlamda, eğitimin amac1, sadece bilginin kazandırılması değil, yaratıcılık ve problem çözme için üst düzeyde düşünme stratejilerinin düzenlenmesi ve geliştirilmesini de kapsamalıdır (Çubukçu, 2004b).

Alanyazında görüldüğg̈ gibi, akademik başarı için bireyin hem düşünme stillerini hem de öğrenme stratejilerini etkili bir şekilde kullanılması ve bunlara dönük bireyde bilişsel farkındalık yaratılması önemlidir. Bununla birlikte, bu durum, bireyin hangi düşünme stillerini ve öğrenme stratejilerini kullandığı, düşünme stilleri ile öğrenme stratejilerinin birbiri ile bir ilişki içinde olup olmadığı sorularının da sorulmasına neden olmaktadır. Ancak alanyazında öğrencilerin düşünme stilleri ile öğrenme stratejileri arasındaki ilişkiyi belirlemeye yönelik bir çalışmaya ulaşılmamıştır.

\section{Araştırmanın amacı}

$\mathrm{Bu}$ araştırmanın amac1, çalışma grubunda yer alan öğrencilerin düşünme stillerini ve öğrenme stratejilerini ortaya çıkarmak; düşünme stili ile öğrenme stratejileri arasındaki ilişkiyi saptamaya çalışmaktır. Bu temel amaç doğrultusunda aşağıdaki sorulara yanıt aranmıştır;

a. Katılımcıların düşünme stilleri nelerdir?

b. Katılımcıların öğrenme stratejileri nelerdir?

c. Katılımcıların düşünme stilleri ile öğrenme stratejileri arasında anlamlı bir ilişki var midir? 


\section{Yöntem}

\section{Araştırma deseni}

Düşünme stilleri ile öğrenme stratejileri arasındaki ilişkiyi belirlemeyi amaçlayan bu araştırmada ilişkisel tarama modelinden (Karasar, 1998) yararlanılmıştır. İlişkisel tarama modeli, katılımcıların düşünme stilleri ile öğrenme stratejilerini belirlemek ve arasındaki ilişkiyi ortaya koymaya yönelik olarak kullanılmıştır.

\section{Evren ve örneklem}

Araştırma evrenini 2014-2015 öğretim yılında Denizli ilinde Milli Eğitim Bakanlığı'na bağlı ortaöğretim kurumlarında öğrenim gören Onbirinci sınıf öğrencileri oluşturmuştur. Örneklemi ise bu kurumlardan rastlantısal olarak seçilen 5 farklı tür okulun (Anadolu Lisesi, Fen Lisesi, Mesleki ve Teknik Anadolu Lisesi, Endüstri Meslek Lisesi ve Sosyal Bilimler Lisesi) Onbirinci sınıflarında öğrenim gören 389 öğrenci oluşturmuştur. Katılımcılara ait betimleyici bilgiler Tablo 3'te sunulmuştur.

Tablo 3. Katılımcılara Ait Betimleyici İstatistikler

\begin{tabular}{lcccccc}
\hline Okul Türü & Kadın & $(\%)$ & Erkek & $(\%)$ & Toplam & $\%$ \\
\hline Anadolu Lisesi & 58 & $(29)$ & 43 & $(22)$ & 101 & $(26)$ \\
Fen Lisesi & 39 & $(20)$ & 25 & $(13)$ & 64 & $(16)$ \\
Mesleki ve Teknik Anadolu Lisesi & 59 & $(30)$ & 33 & $(17)$ & 92 & $(24)$ \\
Endüstri Meslek Lisesi & 0 & $(0)$ & 67 & $(35)$ & 67 & $(17)$ \\
Sosyal Bilimler Lisesi & 41 & $(21)$ & 24 & $(13)$ & 65 & $(17)$ \\
\hline Toplam & 197 & $(51)$ & 192 & $(49)$ & 389 & $(100)$ \\
\hline
\end{tabular}

\section{Veri toplama araçları}

Araştırmanın amacını gerçekleştirmek için iki tür veri toplama aracı kullanılmıştır. İlk veri toplama aracı, Zihinsel Benlik-Yönetimi Kuramı'nın öngörüleri doğrultusunda, Sternberg ve Wagner tarafından geliştirilen, Türkçe güvenirlik çalışmaları Buluş (2006) tarafından yapılan Düşünme Stilleri Ölçeği'dir. Söz konusu ölçeğin madde sayısı 65, alpha güvenirlik katsayısı ise 0.81 olarak belirlenmiştir. İkinci veri toplama aracı ise Weinstein ve Mayer tarafından yapılan sınıflandırmanın temel alındığı ve Güven (2008) tarafından geliştirilen Öğrenme Stratejileri Belirleme Ölçeği'dir. Söz konusu ölçeğin madde sayısı 39, Alpha güvenirlik katsayısı ise 0.88 olarak belirlenmiştir.

Güvenirliğe dönük olarak bu çalışmadan elde edilen veriler $(n=389)$ de şu şekildedir: Düşünme Stilleri Ölçeği’ine ait alpha güvenirlik katsayısı 0.96 olarak belirlenmiştir. Ölçeğin alt ölçeğinin güvenirlik katsayıları Tablo 4'te verilmiştir.

Tablo 4. Düşünme Stilleri Alt Ölçeklerinin Güvenirlik Katsayıları

\begin{tabular}{lc}
\hline Düşünme stilleri & Güvenirlik katsayısı \\
\hline Yasama & .87 \\
Yürütme & .83 \\
Yargı & .86 \\
Monarşik & .74 \\
Hiyerarşik & .84 \\
Oligarşik & .78 \\
Anarşik & .81 \\
Global & .80 \\
Lokal & .81 \\
İçsel & .82
\end{tabular}


Tablo 4. Devamı

\begin{tabular}{lc}
\hline Düşünme stilleri & Güvenirlik katsayısı \\
\hline Dişsal & .83 \\
Liberal & .85 \\
Tutucu & .86 \\
\hline
\end{tabular}

Öğrenme Stratejileri Belirleme Ölçeği'ne ait alpha güvenirlik katsayısı bu çalışma için 0.91 'dir ( $n=389$ ). Ölçeğin alt ölçeğinin güvenirlik katsayıları ise Tablo 5'te verilmiştir.

Tablo 5. Öğrenme Stratejileri Alt Ölçeklerinin Güvenirlik Katsayıları

\begin{tabular}{lc}
\hline Strateji & Güvenirlik katsayıs1 \\
\hline Yineleme stratejisi & .66 \\
Anlamlandırma stratejisi & .74 \\
Örgütleme stratejisi & .75 \\
Anlamayı izleme stratejisi & .75 \\
Duyuşsal stratejiler & .61 \\
\hline
\end{tabular}

\section{Verilerin toplanması ve analizi}

Veriler araştırmacı tarafından toplanmıştır. Bu süreçte, öğrencilere gerekli görülen açıklamalar yapılarak öğrencilerin ölçekleri doldurmaları sağlanmıştır. Ölçekleri nasıl dolduracaklarına dair yönerge okunmuştur. Uygulama aşaması 2014-2015 eğitim-öğretim yılı ikinci yarıyıl dönemi boyunca sürmüştür. Envanterler, öğrencilere iki bölümde sunulmuştur. Birinci bölümünde Öğrenme Stratejileri Ölçeği (39 madde), ikinci bölümünde Düşünme Stilleri Ölçeği yer almıştır (65 madde). Elde edilen veriler üzerinde, SPSS 22 (Statistical Package fort he Social Sciences) paket programı kullanılarak, betimsel istatistik çalışmaları yapılmış ve korelasyon katsayıları hesaplanarak araştırmanın soruları yanıtlanmaya çalışılmıştır.

\section{Bulgular}

\section{Onbirinci sınıf öğrencilerinin düşünme stillerine iliş̧kin bulgular}

Araştırmanın birinci alt problemi "Onbirinci sınıf öğrencilerinin düşünme stilleri nelerdir?" şeklinde ifade edilmiştir. Onbirinci sınıf öğrencilerinin düşünme stillerini kullanma düzeylerinin nasıl bir dağılım gösterdiğini bulmak için düşünme stilleri puanlarının ortalamaları ve standart sapma değerleri hesaplanarak Tablo 6'da sunulmuştur.

Tablo 6. Onbirinci Sinı Öğrencilerinin Düşünme Stillerini Kullanma Durumları

\begin{tabular}{|c|c|c|c|c|}
\hline \multicolumn{2}{|c|}{ Düşünme Stilleri } & $N$ & $\bar{X}$ & $S s$ \\
\hline \multirow{5}{*}{ 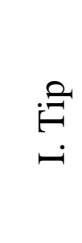 } & Yasama & 389 & 23.88 & 7.829 \\
\hline & Liberal & 389 & 22.23 & 7.135 \\
\hline & Global & 389 & 21.40 & 6.769 \\
\hline & Yarg1 & 389 & 22.51 & 7.417 \\
\hline & Hiyerarşik & 389 & 22.28 & 7.320 \\
\hline \multirow{4}{*}{$\begin{array}{l}\stackrel{0}{F} \\
\dot{\Xi}\end{array}$} & Lokal & 389 & 20.13 & 6.789 \\
\hline & Monarşik & 389 & 21.69 & 6.558 \\
\hline & Muhafazakâr & 389 & 19.87 & 7.627 \\
\hline & Yürütme & 389 & 23.35 & 7.162 \\
\hline \multirow{4}{*}{$\begin{array}{l}\stackrel{\vartheta}{\ominus} \\
\Xi \\
\Xi\end{array}$} & Anarşik & 389 & 20.34 & 6.991 \\
\hline & Oligarşik & 389 & 20.66 & 6.764 \\
\hline & İçsel & 389 & 22.21 & 7.119 \\
\hline & Dişsal & 389 & 21.36 & 7.128 \\
\hline
\end{tabular}


Tablo 6 incelendiğinde, araştırmaya katılan Onbirinci sınıf öğrencilerinin sırasıyla en çok kendi kurallarını oluşturmayı ve yaptıkları işlerde kendilerine özgü olmayı seven yasama düşünme stilini ( $\bar{X}=23.88$ ); kendi kurallarına ya da diğerlerinin yönergelerine uymayı seven ve kendisine söylenenleri yapan yürütme düşünme stilini $(\bar{X}=23.35)$; değerlendirme, yargılama, karşılaştırmayı seven yargı düşünme stilini $(\bar{X}=22.51)$ tercih ettikleri görülmüştür. Bunun yanı sıra işlerini geleneksel yollarla yapmayı seven tutucu düşünme stilini $(\bar{X}=19.87)$; detaylara önem veren lokal düşünme stilini $(X=20.13)$; işlerin öncelik sırasını belirlemekte güçlük çeken oligarşik düşünme stilini $(\bar{X}=20.66)$; problemlere rastgele bir yaklaşım sergileyen anarşik düşünme stilini $(\bar{X}=20.34)$ en az tercih ettikleri görülmektedir.

\section{Onbirinci sınıf öğrencilerinin öğrenme stratejilerine ilişkin bulgular}

Araştırmanın ikinci alt problemi, "Onbirinci sınıf öğrencilerinin kullandıkları öğrenme stratejilerinin neler olduğudur". Bunu belirlemek amacıyla Onbirinci sınıf öğrencilerinin öğrenme stratejilerini belirleme ölçeğinin alt ölçeklerinden elde ettikleri puan ortalamaları bulunmuştur. Onbirinci sınıf öğrencilerinin alt ölçeklerden aldıkları puan ortalamaları ile puan dağılımlarının standart sapmaları Tablo 7'de verilmiştir.

Tablo 7. Onbirinci Sinıf Öğrencilerinin Öğrenme Stratejilerini Kullanma Durumları

\begin{tabular}{lccc}
\hline Ölçek & $N$ & $\bar{X}$ & $S s$ \\
\hline Yineleme Stratejileri & 389 & 14.45 & 4.456 \\
Anlamlandırma Stratejileri & 389 & 28.22 & 7.236 \\
Örgütleme Stratejileri & 389 & 19.90 & 5.474 \\
Anlamayı İzleme stratejileri & 389 & 22.65 & 6.410 \\
Duyuşsal Stratejiler & 389 & 14.80 & 4.345 \\
\hline
\end{tabular}

Tablo 7'de görüldüğü gibi, Onbirinci sınıf öğrencileri öğrenme stratejilerinin alt ölçeklerinde farklı puan ortalamalarına sahiptir. Buna göre, öğrenciler anlamlandırma stratejileri alt ölçeğinde 28.22 puan ortalaması ile en yüksek puanı elde etmişlerdir. Öğrenciler anlamlandırma stratejilerinden sonra en yüksek puan ortalamasını anlamayı izleme stratejilerinden elde edilmişlerdir. Onbirinci sınıf öğrencilerinin bu ölçekteki puan ortalaması 22.65 olarak hesaplanmıştır. Bu stratejiden sonra en çok kullanılan strateji puan 19.90 ortalama ile örgütleme stratejisidir. Onbirinci sınıf öğrencilerinin bu stratejiden sonra en çok kullandıkları strateji 14.80 ortalama ile duyuşsal stratejilerdir. Bununla birlikte, Onbirinci sınıf öğrencilerinin diğer stratejilere göre daha az kullandıkları strateji puan ortalaması 14.45 olarak hesaplanan yineleme stratejisidir. Onbirinci sınıf öğrencileri anlamlandırma stratejileri ve anlamayı izleme stratejilerini daha çok kullanırken örgütleme stratejileri, duyuşsal stratejiler ve yineleme stratejilerini daha az kullanmaktadır.

\section{Onbirinci Sınıf Öğrencilerinin düşünme stilleri ile öğrenme stratejileri arasında ilişki olup olmadığına ilişkin bulgular}

Araștırmanın üçüncü alt problemine ilișkin olarak, Onbirinci Sınıf öğrencilerinin düșünme stilleri ile öğrenme stratejileri arasında istatistiksel olarak ilişki olup olmadığı belirlemek amacıyla korelasyon dağılımlarına bakılmıştır. Sonuçlar Tablo 8'de (diğer sayfada) verilmiştir. Tablo 8'e göre düşünme stili alt boyutları ile öğrenme stratejileri alt boyutları arasında çoğunlukla negatif yönde ilişki olduğu göze çarpmaktadır. Bu kapsamda negatif yönde en yüksek ilişkinin hiyerarşik düşünme stili ile anlamayı izleme stratejileri ve duyuşsal stratejiler arasında olduğu tespit edilmiştir $(r=-.34, p<.01)$. Bu sıralamayı yasama düşünme stili ile duyuşsal stratejiler $(r=-.34, p<.01)$, hiyerarşik düşünme stili ile anlamlandırma stratejileri $(r=-$ $.336, p<.01)$ takip etmiştir. 
Tablo 8. Onbirinci Sınıf Öğrencilerinin Düşünme Stillerinin Alt Boyutları ile Öğrenme Stratejilerinin Alt Boyutları Arasındaki Korelasyon Dağılımları

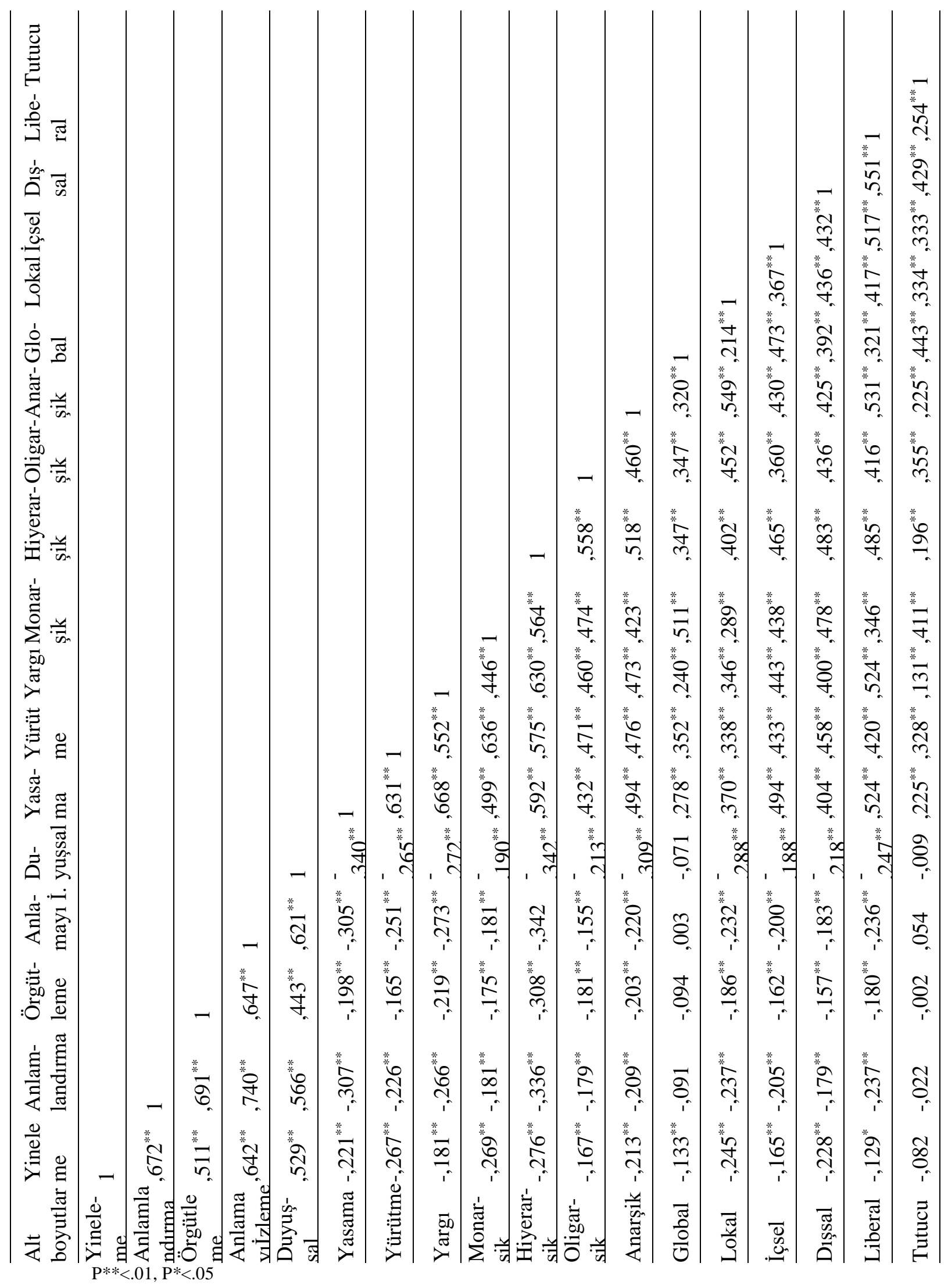


Tablo 8 incelendiğinde, öğrenme stratejileri alt boyutları arasında ki en yüksek ilişkinin ise anlamayı izleme ile anlamlandırma stratejileri arasında olduğu görülmektedir $(r=.74$, $p<.01)$. Bu ilişki düzeyini sırasıyla örgütleme ile anlamlandırma stratejileri $(r=.69, p<.01)$ ve anlamlandırma ile yineleme stratejileri $(r=.67, p<.01)$ takip etmektedir.

Düşünme stili ile öğrenme stratejileri arasındaki ilişkinin incelendiği bu araştırmada negatif yönde çıkan korelasyonun daha iyi açıklanabilmesi adına, okul türüne göre (Anadolu Lisesi, Fen Lisesi, Mesleki ve Teknik Anadolu Lisesi, Endüstri Meslek Lisesi ve Sosyal Bilimler Lisesi) ayrı ayrı ele alınmıştır. İlk olarak Anadolu Lisesi öğrencilerinin düşünme stilleri ile öğrenme stratejileri arasındaki ilişkiye bakılmış ve analiz sonuçları Tablo 9'da verilmiştir.

Tablo 9. Anadolu Lisesi Öğrencilerinin Düşünme Stilleri ile Öğrenme Stratejileri Arasındaki Korelasyon Dağılımları

\begin{tabular}{lccccc}
\hline Anadolu Lisesi & Yineleme & Anlamlandırma & Örgütleme & Anlamayı izleme & Duyuşsal \\
\hline Yasama &,- 394 &,- 541 &,- 327 &,- 539 &,- 482 \\
Yürütme &,- 408 &,- 491 &,- 272 &,- 496 &,- 454 \\
Yarg1 &,- 417 &,- 561 &,- 415 &,- 568 &,- 427 \\
Monarşik &,- 416 &,- 375 &,- 329 &,- 390 &,- 277 \\
Hiyerarşik &,- 500 &,- 585 &,- 445 &,- 610 &,- 598 \\
Oligarşik &,- 300 &,- 337 &,- 388 &,- 430 &,- 272 \\
Anarşik &,- 347 &,- 423 &,- 277 &,- 455 &,- 438 \\
Global &,- 244 &,- 126 &,- 092 &,- 062 &,- 258 \\
Lokal &,- 390 &,- 433 &,- 280 &,- 405 &,- 407 \\
İşel &,- 349 &,- 452 &,- 387 &,- 360 &,- 366 \\
Dişsal &,- 399 &,- 400 &,- 306 &,- 433 &,- 482 \\
Liberal &,- 180 &,- 386 &,- 262 &,- 393 &,- 408 \\
Muhafazakâr &,- 121 &,- 029 &,- 040 &, 062 &,- 107 \\
\hline
\end{tabular}

Tablo 9 incelendiğinde negatif yönde ilişkiler göze çarpmaktadır. Hiyerarşik düşünme stili ile anlamayı izleme stratejileri arasında negatif yönlü ve orta düzeyde bir korelasyon olduğu görülmektedir ( $r=-.61)$. Buna göre, Anadolu Lisesi öğrencelerinin stratejileri ile uyumlu bir stil veya stillerine uygun bir strateji kullanmadıkları söylenebilir. Anlamayı izleme stratejileri ile Tutucu düşünme stili arasında anlamlı bir korelasyon olmamakla birlikte pozitif yönde bir ilişki olduğu görülmektedir.Fen Lisesi öğrencilerinin korelasyon dağılımlarına bakılmış ve analiz sonuçları Tablo 10'da veriliştir.

Tablo 10. Fen Lisesi Öğrencilerinin Düşünme Stilleri ile Öğrenme Stratejileri Arasındaki Korelasyon Dağılımları

\begin{tabular}{lccccc}
\hline Fen Lisesi & Yineleme & Anlamlandırma & Örgütleme & Anlamayı izleme & Duyuşsal \\
\hline Yasama &, 037 &,- 113 &,- 038 &,- 166 &,- 327 \\
Yürütme &,- 242 &,- 012 &,- 112 &,- 164 &,- 131 \\
Yarg1 &, 253 &, 107 &, 204 &, 118 &,- 035 \\
Monarşik &,- 127 &, 010 &,- 052 &,- 046 &,- 006 \\
Hiyerarşik &,- 088 &,- 053 &,- 040 &,- 142 &,- 165 \\
Oligarşik &,- 063 &,- 081 &, 069 &, 031 &,- 147 \\
Anarşik &,- 164 &,- 194 &,- 224 &,- 227 &,- 243 \\
Global &,- 041 &,- 044 &,- 095 &,- 016 &, 101 \\
Lokal &,- 077 &,- 140 &,- 027 &,- 160 &,- 259 \\
İçsel &,- 004 &,- 045 &,- 005 &,- 134 &,- 140 \\
Dişsal &,- 203 &,- 016 &,- 094 &,- 070 &,- 055 \\
Liberal &, 083 &,- 039 &,- 091 &,- 065 &,- 147 \\
Muhafazakâr &,- 026 &, 071 &, 038 &, 147 &, 092 \\
\hline
\end{tabular}


Tablo 10 incelendiğinde en yüksek ilişkinin yargı düşünme stili ile yineleme stratejileri arasında pozitif yönde ve alt düzeyde ilişki olduğu görülmektedir $(r=.25)$. Bu sıralamayı yargı düşünme stili ile örgütleme stratejileri takip etmektedir $(r=.20)$. Bu verilerden yola çıkılarak Fen Lisesi öğrencilerinin bilgiyi belirli bir plana göre düzenlediği ve bunu yaparken zihinsel olarak tartışıp uygun şekilde örgütlediği söylenebilir. Fen Lisesi öğrencilerinin düşünme stilleri ve öğrenme stratejileri arasında genellikle negeatif bir korelasyon görülmektedir. En düşük korelasyonun negatif yönde ve düşük düzeyde lokal düşünme stili ile duyuşsal stratejiler arasında olduğu saptanmıştır $(r=-.25)$. Üçüncü olarak Mesleki ve Teknik Anadolu Lisesi öğrencilerinin korelasyon dağılımlarına bakılmış ve analiz sonuçları Tablo 11'de verilmiştir.

Tablo 11. Mesleki ve Teknik Anadolu Lisesi Öğrencilerinin Düşünme Stilleri ile Öğrenme Stratejileri Arasındaki Korelasyon Dağılımları

\begin{tabular}{llllll}
\hline $\begin{array}{l}\text { Mesleki ve } \\
\begin{array}{l}\text { Teknik Anadolu } \\
\text { Lisesi }\end{array}\end{array}$ & Yineleme & Anlamlandırma & Örgütleme & $\begin{array}{l}\text { Anlamay1 } \\
\text { izleme }\end{array}$ & Duyuşsal \\
\hline Yasama &,- 267 &,- 293 &,- 173 &,- 234 &,- 333 \\
Yürütme &,- 243 &,- 151 &,- 083 &,- 050 &,- 171 \\
Yarg1 &,- 121 &,- 125 &,- 213 &,- 166 &,- 292 \\
Monarşik &,- 317 &,- 170 &,- 121 &,- 069 &,- 186 \\
Hiyerarşik &,- 260 &,- 264 &,- 356 &,- 217 &,- 260 \\
Oligarşik &,- 288 &,- 198 &,- 292 &,- 120 &,- 280 \\
Anarşik &,- 214 &,- 108 &,- 161 &,- 084 &,- 336 \\
Lokal &,- 233 &,- 129 &,- 094 &,- 089 &,- 196 \\
İşel &,- 011 &, 036 &, 043 &, 135 &, 089 \\
Dişsal &,- 160 &,- 087 &,- 154 &,- 036 &,- 170 \\
Liberal &,- 201 &,- 175 &,- 162 &,- 212 &,- 283 \\
Muhafazakâr &,- 092 &, 039 &,- 071 &, 208 &, 052 \\
\hline
\end{tabular}

Tablo 11 incelendiğinde, ilişkinin global düşünme stili ile anlamayı izleme stratejileri arasında pozitif yönde ve düşük düzeyde olduğu görülmektedir ( $r=.28)$. Ayrıca Mesleki ve Teknik Anadolu Lisesi öğrencilerinin muhafazakâr düşünme stili ile anlamayı izleme stratejileri arasında bir ilişki mevcuttur $(r=.21)$. Dördüncü olarak Endüstri Meslek Lisesi öğrencilerinin korelasyon dağılımlarına bakılmış ve analiz sonuçları Tablo 12'de verilmiştir.

Tablo 12. Endüstri Meslek Lisesi Öğrencilerinin Düşünme Stilleri ile Öğrenme Stratejileri Arasındaki Korelasyon Dağglımları

\begin{tabular}{lccccc}
\hline Endüstri Mes.Lis. & Yineleme & Anlamlandırma & Örgütleme & Anlama İz. & Duyuşsal \\
\hline Yasama &,- 062 &,- 122 &,- 096 &,- 033 &,- 112 \\
Yürütme &,- 085 &,- 007 &,- 121 &,- 011 &,- 226 \\
Yarg1 &,- 222 &,- 152 &,- 205 &,- 220 &,- 114 \\
Monarşik &,- 196 &,- 032 &,- 118 &,- 154 &,- 288 \\
Hiyerarşik &,- 204 &,- 245 &,- 339 &,- 280 &,- 271 \\
Oligarşik &, 001 &,- 021 &,- 051 &, 060 &,- 189 \\
Anarşik &,- 010 &, 097 &,- 055 &, 081 &,- 184 \\
Global &,- 091 &,- 105 &,- 163 &,- 091 &,- 248 \\
Lokal &,- 175 &,- 160 &,- 225 &,- 191 &,- 265 \\
Icsel &, 026 &, 089 &, 088 &, 055 &,- 076 \\
Dişsal &,- 046 &, 087 &, 093 &, 043 &,- 097 \\
Liberal &,- 220 &,- 175 &,- 143 &,- 258 &,- 097 \\
Muhafazakâr &, 045 &,- 077 &,- 044 &,- 099 &,- 059 \\
\hline
\end{tabular}


Tablo 12 incelendiğinde, ilişkisel olarak negatif yönde ve düşük bir korelasyon mevcuttur. Bunun yanı sıra hiyerarşik düşünme stili ile örgütleme stratejisi arasında $(r=-.34)$, hiyerarşik düşünme stili ile anlamayı izleme stratejileri $(r=-.28)$ arasında ve hiyerarşik düşünme stili ile duyuşsal stratejiler arasında $(r=-.27)$ negatif yönde ve orta düzeyde bir ilişki vardır. Son olarak Sosyal Bilimler Lisesi öğrencilerinin korelasyon dağılımlarına bakılmış ve analiz sonuçları Tablo 13'te verilmiştir.

Tablo 13. Sosyal Bilimler Lisesi Öğrencilerinin Düşünme Stilleri İle Öğrenme Stratejileri Arasındaki Korelasyon Dağılımları

\begin{tabular}{lccccc}
\hline $\begin{array}{l}\text { Sosyal Bilimler } \\
\text { Lisesi }\end{array}$ & Yineleme & Anlamlandırma & Örgütleme & $\begin{array}{c}\text { Anlamay1 } \\
\text { izleme }\end{array}$ & Duyuşsal \\
\hline Yasama &,- 155 &,- 172 &,- 217 &,- 206 &,- 140 \\
Yürütme &,- 128 &,- 118 &,- 124 &,- 131 &,- 102 \\
Yarg1 &,- 144 &,- 256 &,- 292 &,- 195 &,- 237 \\
Monarşik &,- 133 &,- 101 &,- 163 &,- 063 &,- 154 \\
Hiyerarşik &,- 096 &,- 245 &,- 241 &,- 207 &,- 269 \\
Oligarşik &,- 069 &,- 157 &,- 117 &,- 166 &,- 296 \\
Anarşik &,- 138 &,- 184 &,- 217 &,- 184 &,- 159 \\
Global &,- 007 &,- 170 &,- 208 &,- 033 &,- 157 \\
Lokal &,- 221 &,- 217 &,- 242 &,- 230 &,- 318 \\
İçsel &,- 120 &,- 217 &,- 266 &,- 328 &,- 173 \\
Dişsal &,- 167 &,- 238 &,- 174 &,- 212 &,- 149 \\
Liberal &,- 058 &,- 226 &,- 202 &,- 129 &,- 114 \\
Muhafazakâr &,- 141 &,- 143 &,- 076 &,- 169 &,- 162 \\
\hline
\end{tabular}

Tablo 13 incelendiğinde, ilişkisel olarak bütün stil ve stratejilerde negatif yönde bir korelasyon mevcuttur. En yüksek ilişki içsel düşünme stili ile anlamayı izleme stratejileri arasındadır ( $r=-.33)$. Bunu lokal düşünme stili ile duyuşsal stratejiler $(r=-.32)$ ile oligarşik düşünme stili ile duyuşsal stratejiler $(r=-.30)$ takip etmektedir.

\section{Sonuç ve Tartışma}

Araştırmaya katılan Onbirinci sınıf öğrencilerinin yaratıcılık temelli olan ve I. Tip düşünme stilleri olarak da adlandırılan yasama, hiyerarşik, yargı ve liberal düşünme stillerini oldukça sık tercih ettikleri görülmüsstür. Bunun yanı sıra norm ve kurallara uymayı tercih eden 2. Tip düşünme stillerinden Tutucu, lokal ve global düşünme stillerini ve 3. Tip düşünme stillerinden oligarşik düşünme stili en az tercih ettikleri görülmüştür. Araştırmaya katılan Onbirinci sınıf öğrencilerinin sırasıyla en çok kendi kurallarını oluşturmayı ve yaptıkları işlerde kendilerine özgü olmayı seven "yasama düşünme stili”ni; kendi kurallarına ya da diğerlerinin talimatlarına uymayı seven ve kendisine söylenenleri yapan "yürütme düşünme stili”ni; ve değerlendirme, yargılama, karşılaştırmayı seven "yargı düşünme stili”ni tercih ettikleri görülmüştür. Bunun yanı sıra işlerini geleneksel yollarla yapmayı seven Tutucu düşünme stilini; detaylara önem veren lokal düşünme stilini; işlerin öncelik sırasını belirlemekte güçlük çeken oligarşik düşünme stilini ve problemlere rastgele bir yaklaşım sergileyen anarşik düşünme stilini en az tercih ettikleri görülmektedir. Bu durum Onbirinci sınıf öğrencilerinin yaratıcılık, analiz, karşılaştırma ve planlama gerektiren etkinliklerde yer almayı tercih ettiklerinin; işlerini ya da görevlerini prosedürlere bağlı kalmadan yapmayı sevdiklerinin göstergesi olabilir. Düşünme stillerini kullanma durumlarına göre; Balgamış ve Baloğlu (2005) çalışmada en çok tercih edilen düşünme stili özerk (yasama), kuralcı (yürütme) ve yargılayıcı (yarg1) düşünme stili iken ögrenciler tarafindan en az tercih edilen düşünme stillerini gelenekçi (muhafazakâr), dişadönük (dışsal) ve kuralsız (anarşik) düşünme stilleri oluşturmaktadır. Bu çalışmada da 1. Tip düşünme stilleri olarak da adlandırılan yasama, hiyerarşik, yargı ve liberal düşünme stillerini oldukça sık tercih ettikleri görülmüştür. Bu bilgi, Çubukçu (2004a), Buluş (2005), Saracaloğlu, Yenice ve 
Karasakaloğlu (2008) ve Dinçer, (2009) tarafından yapılan araştırma bulgularıyla paralellik göstermektedir.

Araştırmanın ikinci alt problemi doğrultusunda; Onbirinci sınıf öğrencilerinin öğrenme stratejilerinin nasıl bir dağılım gösterdiğine bakılmıştır. Bu bağlamda, Onbirinci sınıf öğrencileri anlamlandırma stratejileri ve anlamayı izleme stratejilerini daha çok kullanırken, örgütleme stratejileri duyuşsal stratejiler ve yineleme stratejilerini ise daha az kullanmaktadır. Bu bulgular kimi araştırma bulguları ile tutarlılık göstermektedir. Güven (2004), araştırmasında ortaöğretim öğrencilerinin en çok anlamlandırma stratejileri (\%41) ile anlamayı izleme stratejilerini (\%34), en az ise yineleme ve örgütleme stratejiler (\%23) olarak bulmuştur. Bu bulgular, bu çalışmada bulunan anlamlandırma stratejilerinin daha çok ve örgütleme stratejilerinin daha az kullanıldığı bulgularını desteklemektedir. Farklı eğitim düzeylerinde öğrenim gören öğrenciler üzerinde yapılan çalışmalarda da bu araştırmanın bulgularına benzer sonuçlar elde edilmiştir. Weinstein ve Mayer (1979) (Akt: Güven, 2004) tarafından yapılan çalışmada, anlamlandırma stratejilerinin farklı eğitim düzeylerinde (yüksek lisans öğrencilerinin \%83'ü, lisans öğrencilerinin \%41'i, lise öğrencilerinin \%27'si ve ortaokul mezunlarının \%24'ü) sıklıkla kullanıldığı, yineleme stratejilerinin ise yüksek lisans ve lise öğrencileri tarafindan daha az kullanıldığı, lise ve ortaokul mezunu öğrencilerin ise bu stratejileri sıklıkla kullandıkları belirlenmiş̧ir. Bu bulgular, araştırmada bulunan anlamlandırma stratejilerinin daha çok, yineleme stratejilerinin daha az kullanıldığı bulguları ile tutarlılık göstermektedir. Şahin ve Uyar (2013) araştırma sonuçlarına göre öğrencilerin \%41'i tekrar, \%23'ü anlamlandırma, \%20'si dikkat, \%8'i üst bilişsel, \%6's1 duyuşsal ve \%2'si hatırlama stratejilerini kullanmaktadır. Aydın (2011) ortaöğretim öğrencilerinin coğrafya derslerinde en çok "örgütleme stratejilerini" en az ise "planlama stratejilerini" kullandıklarını ortaya çıkarmıştır. Öğrencilerin coğrafya dersinde kullandıkları öğrenme stratejileri ölçeğine ilişkin görüşleri "cinsiyet" ve "öğrenim gördükleri sınıf düzeyleri”" değişkenlerine göre anlamlı farklılık göstermiştir. Yücel ve Taşdemir'in (2012) bulgularına göre, öğrenciler hatırlama, biliş, dikkat, anlamlandırma ve zihne yerleştirme stratejilerini her zaman kullanırken, tekrar stratejilerini sıklıkla ve duyuşsal stratejileri ara sıra kullanmaktadırlar. Güven (2004), araştırmasında orta öğretim öğrencilerinin en çok anlamlandırma stratejileri (\%41) ile anlamayı izleme stratejilerini (\%34), en az ise yineleme ve örgütleme stratejilerini (\%23) kullandığını belirlemiştir. $\mathrm{Bu}$ bulgular, bu çalışmada bulunan anlamlandırma stratejilerinin daha çok ve örgütleme stratejilerinin daha az kullanıldığg bulguları ile tutarlık göstermektedir. Farklı eğitim düzeylerinde öğrenim gören öğrenciler üzerinde yapılan çalışmalarda da bu araştırmanın bulgularına benzer sonuçlar elde edilmiştir.

Araştırmanın üçüncü alt problemi doğrultusunda; Onbirinci sınıf öğrencilerinin düşünme stilleri ile öğrenme stratejileri arasındaki ilişkiye bakılmıştır. Araştırmada okul türlerinin toplam korelasyonuna bakıldığında negatif yönde bir ilişki olmakla birlikte, okul türleri ayrı ayrı incelediğinde yargı düşünme stili ile örgütleme stratejisi arasında; Tutucu düşünme stili ile anlamayı izleme stratejileri arasında; global düşünme stili ile anlamayı izleme stratejileri arasında pozitif yönde bir ilişki olduğu tespit edilmiştir. Bunun yanında akademik başarıları yüksek olan okullarda düşünme stilleri ile öğrenme stratejileri arasındaki ilişki negatif yönde ancak düşük düzeydedir. Akademik başarıları düşük okullarda ise düşünme stilleri ile öğrenme stratejileri arasındaki ilişki negatif yönde ancak yüksek düzeydedir. Düşünme stilleri ile öğrenme stratejileri arasındaki ilişkileri gösteren tablolara bakıldığında öğrencilerin düşünme stillerine uygun öğrenme stratejileri ya da öğrenme stratejilerine uygun düşünme stili belirlemede zorluk yaşadıkları söylenebilir. Buna göre, eldeki araştırmada katılımcıların işlerini kendileri yapmaktan hoşlandıkları fakat buna uygun stratejiyi kullanmadıkları görülmektedir. Araştırmacılar, bu durumun öğrencilerin stillerine uygun bir strateji ya da stratejilerine uygun bir stil seçememelerinden kaynaklandığını düşünmektedirler. Keza, Pressley ve Harris (1990)'e göre, her öğrencinin kendine uygun bir öğrenme stratejisi vardır ancak kendisi için en uygun olan öğrenme durumunu henüz keşfetmemiş olabilir. Öğrencilerin öğrenme stratejilerini etkili bir şekilde kullanamamalarının temelinde bilgi yetersizliği yatmaktadır. 


\section{Kaynaklar}

Aydın, F. (2011). Ortaöğretim öğrencilerinin coğrafya derslerinde kullandıkları öğrenme stratejileri. Turkish Studies, 6(2), 199-212.

Balgamış, E. ve Baloğlu, M. (Eylül, 2005). Lise öğrencilerinin matematik başarıları ile düşünme stilleri arasındaki ilişki. Sözel bildiri, XI. Ulusal Eğitim Bilimleri Kongresi. Denizli: Pamukkale Üniversitesi Eğitim Fakültesi.

Balkis, M. ve Isiker, G. B. (2005). The relationship between thinking styles and personality types. Social Behavior and Personality. 33, 283-295.

Belet, D.Ş. (2005). Öğrenme stratejilerinin okuduğunu anlama ve yazma becerileri ile türkçe dersine ilişsin tutumlara etkisi. Yayınlanmamış doktora tezi, Eskişehir: Anadolu Üniversitesi Eğitim Bilimleri Enstitüsü.

Buluş, M. (2001). Eğitimde gözardı edilen bir konu: düşünme stilleri. Yaşadıkça Eğitim, 72, 27.

Buluş, M. (2005). İlköğretim bölümü öğrencilerinin düşünme stilleri profili açısından incelenmesi. Ege Ĕ̈itim Dergisi, 1(6), 1-24.

Buluş, M. (2006). Düşünme stilleri ölçeğinin güvenirliği ve geçerliği, akademik başarı ve öğretmen adayları özellikleri. Eğitim ve Bilim, 31(139), 35-48.

Çubukçu, Z. (2004a). Öğretmen adaylarının düşünme stillerinin belirlenmesi. Trakya Üniversitesi Sosyal Bilimler Dergisi, 5(2), 87-106.

Çubukçu, Z. (2004b). Öğretmen adaylarının düşünme stillerinin öğrenme biçimlerini tercih etmelerindeki etkisi. Sözel bildiri. XIII. Ulusal eğitim bilimleri kurultayı, Malatya: İnönü Üniversitesi.

Dinçer, B. (2009). Öğretmen adaylarının düşünme stilleri profillerinin çeşitli değişkenler açısından değerlendirilmesi. Yüksek lisans tezi. Aydın: Adnan Menderes Üniversitesi, Sosyal Bilimler Enstitüsü.

Dinçer, B. ve Saracaloğlu, A. S. (2011). Öğretmen adaylarının düşünme stilleri profillerinin çeșitli değişkenler açısından incelenmesi. Türk Ĕ̈itim Dergisi, 9(4), 701-744.

Doğan, B. (2002). Strateji öğretiminin işbirlikli ve geleneksel sinıflarda okuduğunu anlama becerileri, güdü ve hatırda tutma üzerindeki etkileri. Yayımlanmamış doktora tezi. İzmir: Dokuz Eylül Üniversitesi, Eğitim Bilimleri Enstitüsü.

Duru, E. (2004). Düşünme stilleri: kavramsal ve kuramsal çerçeve. Ĕ̈itim Araş̧tırmaları Dergisi, 14, 171- 186.

Emir, S. (2011). Düşünme stillerinin farklı değişkenler açısından incelenmesi. Hasan Ali Yücel Ĕgitim Fakültesi Dergisi, 15, 77-93.

Eyüpoğlu, F. (2010). Eğitimde stil kavramına ilişkin bir inceleme. Türk Eğitim Dergisi, 8(3), 569-592.

Güven, M. (2004). Öğrenme stilleri ile ögrenme stratejileri arasındaki ilişki. Yayımlanmış doktora tezi. Eskişehir: Anadolu Üniversitesi, Eğitim Bilimleri Enstitüsü.

Güven, M. (2008). Development of learning strategies scale: study of validation and reliability. World Applied Sciences Journal, 4(1), 31-36.

Karasar, N. (1998). Araştırmalarda rapor hazırlama yöntemi. Ankara: Pars Matbaacılık Sanayi.

Pressley, M., \& Harris, K.R. (1990). What we really know about strategy instruction. Educational Leadership, September, 31-35.

Riding, R., \& Rayner, S. (1998). Cognitive styles and learning strategies. London: David Fulton Publishers.

Saracaloğlu, A. S., Yenice, N. ve Karasakaloğlu, N. (2008). Eğitim fakültesi öğrencilerinin düşünme stillerinin çeşitli değişkenler açısından karşılaştırılması. Uluslararası Sosyal Araştırmalar Dergisi, 1(5), 732-751.

Sternberg, R. J. (1994). Allowing for thinking styles. Educational Leadership, 52(3), 36-40.

Sternberg, R. J. (1997). Thinking styles. New York: Cambridge University Press.

Sternberg, R. J., \& Zhang, L. F. (2005). Styles of thinking as a basis of differentiated instructon. Theory into Practice, 44(3), 245-253. 
Sünbül, A. M. (2004). Düşünme stilleri ölçeğinin geçerlik ve güvenirliği. Eğitim ve Bilim, $29(132), 25-42$.

Şahin, H. ve Uyar, M. (2013). Öğrenme stratejileri kullanımının akademik başarıya yansımaları. Abant İzzet Baysal Üniversitesi Ĕgitim Fakültesi Dergisi, 13(1), 164-177.

Talu, N. (1997). Ankara özel tevfik fikret lisesi 10.sinı öğrencilerinin kullandıkları öğrenme stratejilerinin akademik başarıları üzerindeki etkisi. Yayınlanmamış doktora tezi. Ankara: Hacettepe Üniversitesi, Eğitim Bilimleri Enstitüsü.

Yücel T. ve Taşdemir A. (2012). İlköğretim 5. sınıf fen ve teknoloji dersinde öğrencilerin kullandıkları öğrenme stratejilerinin irdelenmesi. Sözel bildiri, X. Ulusal Fen Bilimleri ve Matematik Ĕgitimi Kongresi. Niğde: Niğde Üniversitesi.

Yıldız, N. (2003). İlkögrretim 5.sinıf fen bilgisi dersinde ögrencilere kazandırılan öğrenme stratejilerinin ögrencilerin akademik başarıları ve hatırda tutma düzeyleri üzerindeki etkisi. Yayınlanmamış yüksek lisans tezi. Eskişehir: Anadolu Üniversitesi, Eğitim Bilimleri Enstitüsü.

Zhang, L. F. (2000). Are thinking styles and personality types related? Educational Psychology, 20(3), 271-283.

Zhang, L. F. (2003). Contributions of thinking styles to critical thinking dispositions, The Journal of Psychology, 137(6), 517-544.

Zhang, L. F. (2007). Intellectual styles and academic achievement among senior secondary school students in rural China, Educational Psychology, 27(5), 675-692.

\section{Extended Abstract}

\section{Introduction}

The future of society, thinking, creativity and the reasoning of power will find direction with cultivating of high individuals. Change in the subject of the living conditions has brought a different perspective to the education system. The aim of the present study is only to gain knowledge, acception of knowledge without questioning, in this kind of direction the behavior of exhibiting individuals is not enough to be mature. Instead of assimilating the acquired information, the format in accordance with its own style, with independent thinking skills, will develop their creativity and can organize high-level thinking strategies for problem solving, which aims to educate qualified individuals. For this purpose attitude owned by individuals, personality traits and other factors such as physical and spiritual needs should be determined. In light of the information obtained, the best way to reveal the individual's thinking is to get the help to understand a little bit of the complexity of human beings, which will allow more robust steps to be taken in the future. Learning to learn, process to develop effective learning is one of the intended size. In modern era students are needed who can think creatively and independently, can have easy access to information, which can contribute to the production, analysis, with the synthesis and evaluation of critical thinking skills with power to do, investigating and questioning etc. Using both appropriate for that individual thinking styles and obtaining information is very important in terms of providing mental tactics to appropriate learning strategies in the learning process. Individuals to acquire new knowledge, thinking styles and learning strategies they use to perform a learning task. Thinking styles, various cases encountered by individuals, is a preferred way to the mental problems. Learning strategies in mental tactics can perform during the learning of the learner. In learning strategies behavior and thought processes are used by the learner like, the placing of the memory of subject matter and bringing back it to dealing process, many things affects the learning of the learner. As we have seen that thinking styles and learning strategies are two separate items close to each other, which makes sense if it complement each other. Only knowing the thinking styles and learning strategies of individuals their own is not enough. In terms of education it is also important to think that how the process information is being reflected. If the views of individual, interests, taste and physical abilities, shows the difference from each other according to the knowledge, 
then in the mental development (the mental scheme) the learning and thinking activities (styles) will also vary some differences. In order to achieve the targeted success in education; individuals thinking styles and learning strategies for the development, thinking styles they use to be aware of the learning strategy is the provision of a number of important steps to be taken to become responsible for their own learning. By identifying of learning strategies and thinking styles of students that how they frequently use it, are important to help in intervening to determine from learning to learn. Therefore identifying the learning strategy with thinking styles of students are important to achieve in order to reach the desired point in education are necessary investments for the future. In this aspect the harmony between thinking styles and learning strategies are also having the great importance. The aim of this research is to determine of learning strategies and thinking styles and uncover the relationship between learning strategies and thinking styles of the students participating it in.

\section{Method}

The study was designed according to the relational model of the survey method. Research depends on the Ministry of Education of Denizli in the 2014-2015 academic years of secondary schools; sample is selected at randomly from these 5 different types of schools (High School Science High School, Vocational and Technical High School, Vocational School and Social Sciences College) has 389 students from grade $11^{\text {th }}$ classes. Sternberg-Wagner (1992) Thinking Styles Inventory, whose reliability and validity studies were performed by Buluş (2005) and Weinstein - Mayer (1986), learning strategies determining scale, whose reability and validity studies were performed by Güven (2004) employed as data gathering instrument in this study. To analyze the data; number, percentage, mean, standard deviation, t-test, one-way ANOVA, Tukey HSD test, Kruskal-Wallis test and Pearson Product Moment analysis was performed.

\section{Result and Discussion}

According to research findings; students of grade 11th as Type 1 conceptualized thinking styles prefered as legislative, hierarchical, justice and liberal thinking styles frequently. It appeared to have at least conservative, oligarchic, local and global thinking styles. It is consistent with the findings made by the researchs Balgamış and Baloğlu (2005) Çubukçu, (2004a); Buluş, (2005); Saracaloğlu, Yenice and Karasakaloğlu, (2008) and Dinçer, (2009). The strategy used by students in learning strategies and understanding the meaning of the intensive monitoring strategies, affective strategies, recurrence strategies and organizational strategies are determined to use less. It is consistent with the findings made by the researchs Uyar (2013), Yücel and Taşdemir (2012), Güven (2004). Students of grade 11th think with their own style to reveal the relationship between learning strategies, while looking at the total correlations of all types of schools, thinking styles used by students are found to have a negative correlation between learning strategies. According to Pressley and Harris (1990), each student's learning has its appropriate strategy but may not yet discovered the most suitable learning situation for himself. Students use the learning strategies are not effectively on the basis of their failure or lack of knowledge. 